\title{
Characterization and comparation test of chicken eggs strain isa brown and hyline brown in different areas
}

\author{
Setiawan Hakim, Y L Henuk, Hamdan, I Sembiring and Hasnudi \\ Animal Production Study program, Faculty of Agriculture Universitas Sumatera Utara, Padang \\ Bulan Medan 20155 \\ Setiawanhakim@gmail.com
}

\begin{abstract}
This study aims to determine the characterization and comparative test of exterior and interior qualities including egg weight, eggshell thickness, egg shape, air cavity and interior including high albumin, egg yolk, and haugh egg unit from egg strain Isa Brown and Hyline Brown in different areas of Deli Serdang and Langkat regencies, North Sumatra Province in June-July 2017. The eggs used in this study were 400 eggs divided by 100 Isa Brown and 100 Hyline Brown from Denai Village, Pantai Labu Subdistrict, Regency Deli Serdang, then 100 Isa Brown and 100 Hyline Brown from Sei Limbat Village, Kecamatan Selesai, Langkat District. Each egg is collected directly from the chicken and then measured against the exterior and interior. The results showed that the characterization and comparative test of chicken eggs consumption of strains of Isa Brown and Hyline Brown in different regions had results(thit> ttable) with $\mathrm{t}$ test on comparative test $\mathrm{I} 1$ : $\mathrm{H} 1$ and $\mathrm{I} 2$ : $\mathrm{H} 2$ meaning egg of different strain showed different result also on egg weight parameter, shapeegg, shell weight, air cavity, egg white index, haugh unit, egg yolk index and yolk color. The comparative test I1: I2 showed no significant differences (thit <ttabel) on egg weight, shell thickness, shell weight, egg white index, haugh unit and egg yolk index, but showed significantly different (titable) results in egg shape, air cavity and yolk color, meaning there is environmental influence but not significant to other quality of egg with same strain in different region. In the $\mathrm{H} 1$ : $\mathrm{H} 2$ comparative test the results were not significantly different (thit <ttabel) on all parameters except the color of egg yolks, meaning that no environmental or strain effect produced eggs of the same quality in different regions.
\end{abstract}

\section{Introduction}

Eggs are one of the livestock products that give a big influence on the nutritional adequacy of Indonesian society. From an egg obtained complete nutritional content ranging from protein, fat, vitamins and minerals to digested byhumans to be met the nutrients needed by the body, such as growth and development of children, for pregnant mothers and mothers who breastfeed. In addition, eggs have economic value is much cheaper than other sources of animal protein, such as meat and fish. Eggs are economically valuable as wellhas the quality and quality to be maintained so that the eggs consumed are good, healthy and fresh eggs.

Eggs have standards that must be maintained so that consumers can consume eggs that are good for families and other consumers. This is also called egg quality. Egg quality is a general term that refers to some standards that determine both internal and external quality. External quality is focused on skin hygiene, texture, shape, skincolor and egg integrity. Internal quality refers to egg white (albumin), cleanliness and viscosity, air cell size, yolk shape and egg yolk strength.

Data from egg production shows that in every area of North Sumatra province, has many laying hens industry that began to grow and contribute in meeting the needs of food in Indonesia especially in the poultry sector.

The introduction of the character of each type of laying hens can be known in the process of laying chicken maintenance from the initial phase to the peak of production, but in the characterization and quality of the eggs every farm is not known whether there are differences of eggs from different strains, so it needs to be tested against the type of laying hens in the Province of North Sumatra.

Deli Serdang and Langkat are the districts with high percentage of egg distributors. This triggers the author to conduct research on eggs produced by both districts. The type (strain) laying chicken that is kept by the breeders 
Deli Serdang and Langkat district is dominated by strains of Isa Brown and Hyline Brown. Majoritybreeders choose both these strains due to being able to adapt tofast on the environment, showing higher egg production, better chicken endurance and are familiar with the scope of the laying chicken business.

Based on the description above, the authors are willing to do research on the characterization and comparative test of exterior and interior of chicken eggs of Isa Brown and Hyline Brown in two districts namely Deli Serdang and Langkat regency.

\section{Method of collecting data}

The data collected in this study includes primary data and secondary data. Primary data were obtained from egg measurements according to research parameters (egg weight, shell thickness, egg length, air cavity, egg yolk index, egg white index). Secondary data were obtained from various journalsscientific, text book, thesis (research report), as well as other references. The resulting data is tabulated.

\section{Results and discussion}

\subsection{Exterior}

\section{Egg Weight}

Based on the results of the research on the weight characterization of Isa Brown and Hyline Brown eggs in different areas, namely Denai Village, PantaiLabuSubdistrict, Deli Serdang District and SeiLimbat Village, KecamatanSelesai,Langkat Regency obtained characterization data that can be seen in table 2 . Table 2 . Classification of egg weight strain Isa Brown and Hyline Brown.

\begin{tabular}{|c|c|c|c|}
\hline \multirow[t]{2}{*}{ Strain } & \multicolumn{3}{|c|}{ BeratTelur } \\
\hline & Total & Mean \pm Stdev & $\mathrm{KK}$ \\
\hline $\mathrm{I} 1$ & 5559.15 & $55.59 \pm 3.67$ & $6.60 \%$ \\
\hline $\mathrm{I} 2$ & 5573.94 & $55.74 \pm 5.03$ & $9.02 \%$ \\
\hline $\mathrm{H} 1$ & 5707.09 & $57.07 \pm 5.24$ & $9.18 \%$ \\
\hline $\mathrm{H} 2$ & 5789.86 & $57.90 \pm 5.33$ & $9.21 \%$ \\
\hline
\end{tabular}

The results of observation on Isa Brown and Hyline Brown at the age of 25 weeks in different areas, ie I1 has an average egg weight of $55.59 \mathrm{~g}, \mathrm{I} 2 \mathrm{has}$ an average egg weight of $55.74 \mathrm{~g}$, then on $\mathrm{H} 1$ has an average egg weight of 57.07, H2 has an average egg weight of $57.89 \mathrm{~g}$. This is in accordance with the statement of National Standard Body SNI 3926 (2008) states that the size of egg weight is divided into 3, ie small $(<50$ g), medium $(50-60 \mathrm{~g})$, large (>60 g). The standard deviation obtained from each strain and region, which has \pm 3.67 (I1), \pm 5.03 (I2), \pm 5.24 (H1) and $\pm 5.33(\mathrm{H} 2)$. In Table 2 it can be seen that the resulting Coefficient of Diversity $<10 \%$ or the coefficient of diversity is small, meaning the value obtained in uniform conditions. These results explain that the eggs produced are at a production stage that is in accordance with the management guidelines.

\subsection{Egg Shape (Egg Index)}

From the results of the research, it is known that the characterization of egg eggs Isa Brown and Hyline Brown on different areas, namely Denai Village, PantaiLabuSubdistrict, Deli Serdang District and SeiLimbat Village, KecamatanSelesai, Langkat Regency can be seen in table 3.

\begin{tabular}{lccc}
\multirow{2}{*}{$\begin{array}{c}\text { Tabel 3. } \\
\text { konsumsi }\end{array}$} & \multicolumn{2}{c}{$\begin{array}{c}\text { Klasifikasibentuktelur } \\
\text { Isa Brown } \text { danHyline Brown }\end{array}$} & ayam \\
\hline \multicolumn{3}{c}{ Strain } & \multicolumn{3}{c}{ BentukTelur } \\
& & & \\
\cline { 2 - 4 } & Total & Mean \pm Stdev & KK \\
\hline I1 & 7991.15 & $79.91 \pm 2.81$ & $3.52 \%$ \\
I2 & 7691.76 & $76.92 \pm 3.14$ & $4.09 \%$ \\
H1 & 7805.26 & $78.05 \pm 2.81$ & $3.60 \%$ \\
H2 & 7916.47 & $79.16 \pm 5.99$ & $7.57 \%$
\end{tabular}

In the table above got the average value of egg shape from Isa Brown and Hyline Brown from different region isI $1=79.91, \mathrm{I} 2=76.92, \mathrm{H} 1=78.05$ and $\mathrm{H} 2=79.16$ with standard deviation obtained from each \pm 2.81 (I1), \pm $3.14(\mathrm{I} 2), \pm 2.81(\mathrm{H} 1)$ and $\pm 5.99(\mathrm{H} 2)$. These results indicate that the mean value of eggs from both regions is less ideal or eggs are round. According to Sumarni (1995), eggs are both oval and ideally have a "shape index" (SI) between 72-76. Eggs are oval SI $=<72$ and round egg $\mathrm{SI}=>76$. In chicken eggs consumption of egg index 
is not very important, because the purpose of chicken egg consumption is for consumers and has no important role in economic value.

3.3 The thickness of Kerabang

From the results of the research, it is known that the thickness characterization of Isa Brown and Hyline Brown eggs in different areas, namely Denai Village, KecamatanPantaiLabu, Deli Serdang District and SeiLimbat Village, KecamatanSelesai, Langkat Regency can be seen in table4.

Tabel 4. Klasifikasitebalkerabang Isa Brown danHyline Brown

\begin{tabular}{llll}
\hline \multicolumn{2}{c}{ Strain } & \multicolumn{3}{c}{ TebalKerabang } \\
\cline { 2 - 4 } & Total & Mean \pm Stdev & KK \\
\hline I1 & 44.98 & $0.45 \pm 0.10$ & $22.94 \%$ \\
I2 & & & \\
& 45.30 & $0.45 \pm 0.11$ & $24.65 \%$ \\
H1 & & & $23.46 \%$ \\
H2 & 45.22 & $0.45 \pm 0.10$ & $21.01 \%$ \\
\hline
\end{tabular}

The results of the study are seen ontable 4 shows $\mathrm{I} 1=0.45 \pm 0.10, \mathrm{I} 2=0.45 \pm 0.11, \mathrm{H} 1=0.45 \pm 0.10$ and $\mathrm{H} 2=$ $0.45 \pm 0.09$ has a higher mean value compared to the statementSteward and Abbot (1972) which states that chicken egg chicken eggshell thickness ranged from $0.330-0.350 \mathrm{~mm}$. Table 4 can be seenalso the coefficient of diversity of each strain> $20 \%$ or coefficient of large diversity which means the value obtained vary. The cause of the coefficient value of diversity of thickness of the shell by Steward and Abbott (1972) statements influenced by several factors, namely: age, chicken type, food substances, physiological events of the body organs, stress and eggshell layer components. These results explain that the thickness of the shell obtained shows good quality.

3.4 Weight Kerabang

From the results of the research, it is known that the weight characterization of eggshell Isa Brown and Hyline Brown in different areas, namely Denai Village, KecamatanPantaiLabu, Deli Serdang District and SeiLimbat Village, KecamatanSelesai, Langkat Regency can be seen in table 5.

Tabel 5. KlasifikasiberatkerabangIsa

Brown danHyline Brown

\begin{tabular}{llll}
\hline \multicolumn{3}{c}{ Strain } & \multicolumn{3}{c}{ BeratKerabang } \\
\cline { 2 - 4 } & Total & Mean \pm Stdev & KK \\
\hline I1 & 693.89 & $6.94 \pm 0.63$ & $9.06 \%$ \\
I2 & 711.22 & $7.11 \pm 0.67$ & $9.49 \%$ \\
H1 & 729.39 & $7.29 \pm 0.71$ & $9.78 \%$ \\
H2 & 747.80 & $7.48 \pm 1.28$ & $17.19 \%$
\end{tabular}

According to UNECE STANDARD EGG-1 (2010), it states that a good shell is a shell that meets the criteria of normal form, clean (non-stained), undamaged (cracked), thick and smooth, this criterion is categorized one of egg class A criteria and is worth consuming directly by consumers. It is lacking

according to what is found on the farm, there are still many stained eggs, rough kerabangpenduks. The results obtained average value of the weight of the shell $\mathrm{I} 1=6.94 \pm 0.63, \mathrm{I} 2=7.11 \pm 0.67, \mathrm{H} 1=7.29 \pm 0.71$ and $\mathrm{H} 2=$ $7.48 \pm 1.28$.

Air Cavity 
From the results of the research, it is known that the characterization of Isa Brown and Hyline Brown Egg Air Cultivation in different areas ieDenai Village, KecamatanPantaiLabu, Deli Serdang District and SeiLimbat Village, KecamatanSelesai, Langkat Regency can be seen in table 6.

Tabel 6. Klasifikasi Rongga Udara Isa

\begin{tabular}{|c|c|c|c|c|}
\hline \multirow[t]{2}{*}{ Strain } & \multicolumn{2}{|r|}{ Rongga } & \multicolumn{2}{|c|}{ Udara } \\
\hline & Total & Mean \pm & Stdev & KK \\
\hline I1 & 47.65 & $0.48 \pm$ & 0.13 & $28.05 \%$ \\
\hline $\mathrm{I} 2$ & 33.50 & $0.34 \pm$ & 0.16 & $47.76 \%$ \\
\hline $\mathrm{H} 1$ & 28.08 & $0.28 \pm$ & 0.10 & $36.14 \%$ \\
\hline $\mathrm{H} 2$ & 24.05 & $0.25 \pm$ & 0.12 & $47.53 \%$ \\
\hline
\end{tabular}

Brown and Hyline BrownFrom the result data in table 6, it can bewe see that the average airborne values obtained are all different $\mathrm{I} 1=0.48 \pm 0.13, \mathrm{I} 2=0.34 \pm 0.16, \mathrm{H} 1=0.28 \pm 0.10, \mathrm{H} 2=0.25 \pm 0.12$. As for coefficientsthe diversity obtained $>20 \%$, meaning that the value obtained is very diverse. Resultsit is concluded that the egg quality of the air bag factor is still a quality grade I and II or categorizedthe quality of A and B because of the large diversity coefficient indicates there is air cavities that are not on the same quality. These results are in accordance with the statement of SNI National Standards Agency 3926 (2008) that the condition of the airbag (viewed from observation) shall comply air bag depth criteria $<0.5 \mathrm{~cm}$ (quality I), $0.5-0.9 \mathrm{~cm}$ (quality II),> $0.9 \mathrm{~cm}$ (quality III), then the criteria of freedom moving air bag: stay in place (quality I), free to move (quality II), free move and can form air bubbles (quality III).

Interior

3.5 Egg White Index

From the results of the research, it is known that the characterization of White Isa Brown and Hyline Brown Indexes in different areas, namely Denai Village, KecamatanPantaiLabu, Deli Serdang District and SeiLimbat Village, KecamatanSelesai, Langkat Regency can be seen in Table 7.

Tabel 7. KlasifikasiIndeksPutihTelurIsaBrown danHyline Brown

\begin{tabular}{llll}
\hline \multirow{2}{*}{ Strain } & \multicolumn{3}{l}{ IndeksPutihTelur } \\
\cline { 2 - 4 } & Total & $\begin{array}{l}\text { Mean } \pm \\
\text { Stdev }\end{array}$ & KK \\
& & & \\
\hline I1 & 12.08 & $0.12 \pm 0.04$ & $30.01 \%$ \\
I2 & 13.07 & $0.13 \pm 0.04$ & $27.73 \%$ \\
H1 & 13.26 & $0.13 \pm 0.03$ & $24.68 \%$ \\
H2 & 14.02 & $0.14 \pm 0.03$ & $18.66 \%$
\end{tabular}

Result of examination of egg white egg index Isa Brown and Hyline Brown in both regions, in the result of egg white index value $\mathrm{I} 1=0.12 \pm 0.04, \mathrm{I} 2=0.13 \pm 0.04, \mathrm{H} 1=0.13 \pm 0.03, \mathrm{H} 2=0.14 \pm 0.03$ can be seen in table 7 . Value of egg white index (IPT) which is classified all into quality I andII. In the examination results showno spider has conditionsame viscosity, this refers to the coefficient value of $>20 \%$ diversity .This result is in accordance with the statement of National Standard Body SNI 3926 (2008) that the average egg has IPT 0.1340.175(quality I), 0.092-0.133 (quality II), 0.05-0.091 (quality III).

Haugh Unit

From the results of the research, the characterization of Haugh Unit Egg Isa Brown and Hyline Brown in different areas, namely Denai Village, KecamatanPantaiLabu, Deli Serdang District and SeiLimbat Village, KecamatanSelesai, Langkat Regency can be seen in table 8.

Tabel 8. KlasifikasiHaugh Unit Isa BrowndanHylineBorwn

Haugh Unit

\begin{tabular}{llll} 
& Total & Mean \pm Stdev & KK \\
\hline I1 & 7207.87 & $72.08 \pm 6.73$ & $9.34 \%$ \\
I2 & 7274.58 & $72.75 \pm 4.46$ & $6.12 \%$
\end{tabular}


In table 8 it can be seen that the average value of Haugh Unit (HU) egg value in Isa Brown and Hyline Brown in both areas is $\mathrm{I} 1=72.08 \pm 6.73, \mathrm{I} 2=72.75 \pm 4.46, \mathrm{H} 1=74.85 \pm 4.50, \mathrm{H} 2=74.96 \pm 2.85$ can be seen in table 8 . As for the coefficient of diversity obtained $<10 \%$, meaning the value obtained uniform. The freshness of the egg whites of the two regions can be summed up into qualityA A. This result is in accordance with the statementstandard United State Department of Agriculture in the book Sudaryani (2003) who reported the determination of egg quality based on haugh units are as follows:haugh units <31 are classified quality $\mathrm{C}$; haugh unit values between 31-60 are classified as B quality; haugh unit value between 60-72 is classified as A quality; value haugh unit> 72 classified AA quality. Haugh units are the units used to know the freshness of the contents of eggs, especially the egg whites. The higher the haugh unit value of an egg shows that egg quality is getting better.

3.6 Yellow Egg Index

From the results of the research, the characterization of Haugh Unit Egg Isa Brown and Hyline Brown in different areas, namely Denai Village, KecamatanPantaiLabu, Deli Serdang District and SeiLimbat Village, KecamatanSelesai, Langkat Regency can be seen in table 9.

Tabel 9. KlasifikasiIndeksKuningTelurIsaBrown danHyline Brown

\begin{tabular}{llll}
\hline \multirow{2}{*}{ Strain } & \multicolumn{2}{c}{ IndeksKuning } & Telur \\
\cline { 2 - 4 } & Total & $\begin{array}{l}\text { Mean } \pm \\
\text { Stdev }\end{array}$ & KK \\
\hline I1 & 40.57 & $0.41 \pm 0.05$ & $12.44 \%$ \\
I2 & 41.72 & $0.42 \pm 0.06$ & $13.44 \%$ \\
H1 & 43.51 & $0.44 \pm 0.05$ & $12.13 \%$ \\
H2 & 44.19 & $0.44 \pm 0.04$ & $9.84 \%$
\end{tabular}

In table 9 can be seen the results of yolk index on Isa Brown and Hyline Brown found the average index I1 = $0.41 \pm 0.05, \mathrm{I} 2=0.42 \pm 0.06, \mathrm{H} 1=0.44 \pm 0.05$ and $\mathrm{H} 2=0.44 \pm 0.04$ with the coefficient of diversity $<20 \%$. This result is in accordance with the statement of SNI 01-3926-2008 (2008) which states that the index of fresh egg yolk ranges from 0.33-0.52. In this condition, eggs from both regions can be summed up to meet the quality of good eggs and feasible to consume. In this condition, the quality of the egg should be maintained as after the egg period is ejected and enters the storage space. According to Yuwanta (2010), states that the yolk index will decrease from 0.45 to 0.30 if stored for 25 days at $25^{\circ} \mathrm{C}$.

3.6 Egg yolk

The color of egg yolks (WKT) is one of the indicators that can be used to determine egg quality. Based on the results of the examination on eggs Isa Brown and Hyline Brown from both areas it is found that the average color of egg yolk ranged from 6.68-7.47, rounded to the value 7. The results can be seen in table 10.

Tabel 10. Penyebaran yolk colour Isa

Brown danHyline Brown

\begin{tabular}{llllll}
\hline $\begin{array}{l}\text { Yolk } \\
\text { Colo } \\
\text { ur }\end{array}$ & $\begin{array}{l}\text { Warn } \\
\text { a-5 }\end{array}$ & $\begin{array}{l}\text { Warn } \\
\text { a-6 }\end{array}$ & $\begin{array}{c}\text { Warn } \\
\text { a-7 }\end{array}$ & $\begin{array}{l}\text { Warn } \\
\text { a-8 }\end{array}$ & $\begin{array}{l}\text { Tot } \\
\text { al }\end{array}$ \\
\hline I1 & 0 & 13 & 71 & 16 & 100 \\
I2 & 10 & 29 & 44 & 17 & 100 \\
H1 & 0 & 4 & 45 & 51 & 100 \\
H2 & 0 & 17 & 71 & 12 & 100
\end{tabular}

The results of the WKT inspection in Table 10 are not consistent with the statement of Surdayani (2003), which states good egg yolks in the range of 9-12. The cause of this occurrence is a result of the needs of the food is less contains carotene. According Yamamoto et al (1997), the color of egg yolks influenced by feed. If the feed contains more carotene, iesantofil, then the more egg yolks colored orange red. Carotene (Carotenoid) consists of carotene ( $\alpha$ and $\beta$ ) and xanthophyll (cryptoxanthin, lutein and zeaxanthin) in which both of these substances is a coloring pigment for the yolk.

Comparative Test 
Based on the results of the research, comparative test between Isa Brown and Hyline Brown strains in different areas, namely Denai Village, KecamatanPantaiLabu, Deli Serdang District and SeiLimbat Village, KecamatanSelesai, Langkat Regency can be seen in table 11.

Tabel 11. UjiKomparasiIsa BrowndanHyline Brown di Wilayah Berbeda

\begin{tabular}{llllllllll}
\hline Uji & BT & SI & TK & BK & RU & IPT & HU & IKT & WKT \\
Komparasi & & & & & & & & & \\
\hline I1 : I & 0.24 & $7.10^{*}$ & 0.21 & 1.88 & $6.78^{*}$ & 1.93 & 0.83 & 1.53 & $3.40^{*}$ \\
I1 : H1 & $2.31^{*}$ & $4.67 *$ & 0.16 & $3.73^{*}$ & $11.66^{*}$ & $2.41^{*}$ & $3.42^{*}$ & $4.02^{*}$ & $5.57 *$ \\
H1 : H2 & 1.11 & 1.68 & 0.15 & 1.25 & 2.00 & 1.82 & 0.20 & 1.00 & $6.59 *$ \\
I2 : H2 & $2.95^{*}$ & $3.32 *$ & 0.21 & $2.52^{*}$ & $4.28^{*}$ & $2.12^{*}$ & $4.17 *$ & $3.48^{*}$ & $2.63 *$ \\
\hline
\end{tabular}

Keterangan : Data terdiridari 4 perbandingan. Tanda * menunjukkanbahwanilaiberbedanyatapadataraf $5 \%(\alpha=0.05)$ denganuji t $(0.05=$ 1.972).

Table 11 shows that the comparative test of Isa Brown and Hyline Brown eggs in different regions have different characterizations(thit>ttabel) with $t$ test on the parameter of egg weight, egg shape, air cavity, indexegg whites, haugh units, egg yolk index and yolk color. This explains that there is a strain effect that distinguishes from the eggs produced. While the thickness parameters of the shell indicate that the results are not significantly different(thit<ttabel).

While on Isa Brown strains in different regions showed no resultssignificantly different (thit<ttabel) on the parameters of egg weight, thickness of the shell, the weight of the shell,egg white index, haugh unit and yolk index. While on the parameter of egg shape, air cavity and yolk color showed significantly different result (thit $>$ ttabel). This explains the absence of production differences from the same strain and little environmental influence on the quality of the air cavity, whereas the difference between egg yolk is caused by different factors of feed consumed.

In the Hybrid Brown strains in different regions, the results were not significantly different (eggs), egg shape, thickness of the shell, the weight of the shell, the air cavity, the egg white index, the haugh unit, and the egg yolk index. Only the egg yolk color is real different (thit>ttabel). This explains that the same strains in different areas do not affect the quality of Hyline Brown egg production. After the results of each region showed differences in the color of egg yolks.

\section{Conclusions and suggestion}

Characterization and comparation test of chicken egg consumption in different areas showed Hyline Brown strain has better characterization than Isa Brown strain. These results are seen from the comparative test I1: H1 and $\mathrm{I} 2: \mathrm{H} 2$ which states the difference refers to the Hyline Brown strain that has a larger egg value. In the same strains of different regions show the same characterization.

It is also advisable for breeders to consider the selection of Hyline Brown strains as laying hens in the livestock business so that the eggs obtained have heavier eggs than Isa Brown

\section{5.references}

[1]. Abbas, M. H. 1989. PengelolaanProduksiUnggas. Jilid Univesitas Andalas, Padang.

[2]. BadanStandarisasiNasional. 2008. MetodePengujian Cemaran Mikroba dalamDaging, TelurdanSusu, Serta HasilOlahannya. SNI 2897:2008. Jakarta

[3]. Belitz, H. D., danW. Grosch. 1999. Food Chemistry. Springer, Germany.

[4]. Buckle,K.A., R.A.Edward, W.R.Day, G.H.Fleetdan M. Wotton. 1987. IlmuPangan. Universitas Indonesia Press, Jakarta. (DiterjemahkanolehHadiPurnomodanAdiono).

[5]. Djanah,D. 1990. BeternakAYam. CV. Yasaguna. CetakanKedua, Surabaya

Genetic,H. 2006. Diaksesdari http:// www.hendrixgentics.com/layerbreeding. Padatanggal 22 maret 2017

[6]. Hy-Line.2014. Panduan ManajemenHy-LineBrown.

Diaksesdarihttp://hyline.com/aspx/general/dynamicpage.aspx?id=190. padatanggal 21 Maret 2017

[7]. Kartasudjana,R. dan E. Suprijatna. 2006. ManajemenTernakUnggas. PenebarSwadaya, Jakarta.

[8]. Kurtini, T., K. Nova., dan D. Septinova. 2011. ProduksiTernak Unggas.

Universitas Lampung, Bandar Lampung

[9]. Mc Donald, P., R.A. Edwards, J. F D. Greenhalghand C. A. Morgan. 2002.Animal Nutrition. $5^{\text {th }}$ Edition. Longman Scientific and Technical, New York .Diakses 21 Maret 2017

[10]. Rasyaf,M. 2001. BeternakAyamPetelur. PenebarSwadaya, Jakarta Romanoff, A. I. dan A. J. Romanoff. 1963.The Avian Egg. Jhon Willey and Sons.Inc, New York. 
[11]. Scott, M. L., M.C. Nesheim and R. J. Young. 1982. Nutrition of The Chicken. $3^{\text {rd }}$ Edition. M. L. Scott and Associates. Ithaca. New York.

[12].Sudaryani, T. 2003. Kualitas Telur. PT. PenebarSwadaya, Jakarta. 